\title{
Comparison of green tea and probiotic as alternatives to antibiotic growth promoter in broiler ration
}

\author{
MM Hasan', ME Hossain* MAK Azad1, MM Hossain and AS Afsana \\ Department of Poultry Science, Faculty of Animal Husbandry, Bangladesh Agricultural \\ University, Mymensingh-2202, Bangladesh
}

\begin{abstract}
Feed supplements were used up to 35 days in 240 Cobb- 500 broilers divided randomly into four groups. The treatments were: control (basal diet; no additives), antibiotic (basal diet + antibiotic), probiotic (basal diet + protexin) and green tea (basal diet $+0.25 \%$ green tea powder). Body weight and body weight gain increased significantly $(\mathrm{P}<0.05)$ in the antibiotic, probiotic and green tea groups compared to the control. Lower $(P<0.05)$ feed intake and better $(\mathrm{P}<0.05)$ feed conversion ratio occurred in the supplemented groups than the control group. Supplementation of antibiotic and green tea increased $(\mathrm{P}<0.05)$ crude protein content of the meat, while probiotic and green tea decreased $(\mathrm{P}<0.05)$ fat content compared to the control. Gizzard weight increased $(\mathrm{P}<0.05)$ in antibiotic group, whereas wing and caeca weight increased in green tea group. Supplemented groups had decreased $(\mathrm{P}<0.05)$ caecal microbial number compared to the control group. It is suggested that addition of probiotic and green tea improves growth parameters, composition of broiler meat and reduced microbial population. (Bangl. vet. 2018. Vol. 35, No. 1 \& 2, 13 - 24)
\end{abstract}

\section{Introduction}

Antibiotics used in animal feeds as growth promoters raise concern about effects on human health. Bacteria that infect men and animals can become resistant. For this reason, European Union banned the use of antibiotics in animal production from 2006 (1831/2003/EC). The phasing out of antibiotic growth promoters will affect the poultry and animal industry at large. To minimize the loss in growth, there is a need to find alternatives. There are alternatives such as organic acids, probiotics, prebiotics, herbs, and immune stimulants.

A probiotic is a microorganism or combination of microorganisms which selectively suppresses the harmful bacteria in the gut (Coppola and Turns, 2004; Fuller, 1989). The advantages of using probiotics include improved health, feed conversion ratio, and growth rate, resistance to disease, and production (Ahmad et al., 2006; Tannock, 1999; Murshed et al., 2015). Probiotics help in maintaining a healthy gastrointestinal environment through the intake of beneficial microorganisms (FAO/WHO, 2002), which produce vitamin B complex and digestive enzymes, and stimulate intestinal immunity, increasing protection against toxins produced by pathogenic microorganisms (Kyriakis et al., 1999; Alexopoulos et al., 2004).

${ }^{1}$ Department of Animal Science, Faculty of Animal Husbandry, Bangladesh Agricultural University, Mymensingh-2202, Bangladesh

*Corresponding author:- E-mail: mehossain_bau@yahoo.com

DOI: https://doi.org/10.3329/bvet.v35i1-2.53383 
Use of green tea (Camellia sinensis) as growth promoter of broiler diet is a new phenomenon in Bangladesh. The physiological and pharmaceutical effects of green tea have been reported (Ishihara et al., 2001). Green tea contains as many as 200 bioactive compounds such as flavonoids, amino acids, xanthine alkaloids, vitamins and minerals, which are safe for human health. Low grade green tea and green tea byproducts have been used in animal feed (Hossain et al., 2012a; Hossain et al., 2012b). Green tea has anti-carcinogenic (Mukhatar et al., 1999), antimicrobial (Hara-Kudo et al., 2005), antioxidant (Nishida et al., 2006) and immune modulatory properties (Ko et al., 2008). The objective of the study was to compare the effects of antibiotics, probiotics and green tea on growth performance, meat composition, meat yield, internal organ and bone development, and caecal microbial count in poultry in Bangladesh.

\section{Materials and Methods}

\section{Birds, diets and management}

The study was conducted at Bangladesh Agricultural University Poultry Farm, Mymensingh. A total of 240 one-day-old straight run (mixed sex) Cobb 500 commercial broiler chicks were used for 35 days and randomly distributed in four groups of 15. Starter diet was provided for the first 21 days and grower diet from 22 days of age until end of the study. A corn-soya based diet was formulated (Cobb Breeder Management Guide, 2012) and fed ad libitum. The composition of the basal diet is shown in Table 1.

Group 1 was control group with no additives. In group 2, $0.025 \%$ antibiotic (oxytetracycline) was mixed with basal diet. In group 3, $0.01 \%$ probiotic (protexin) and in group $4,0.25 \%$ green tea were mixed with basal diet. Chicks were given 23 hours and 30 minutes of light and 30 minutes of darkness. Temperatures began at $32^{\circ} \mathrm{C}$ for one week, with a gradual decrease of $3^{\circ} \mathrm{C}$ for both the second and third week, before it was settled at a stable $22^{\circ} \mathrm{C}$ for the study period. The floor space allowed for each bird was 1 sq. $\mathrm{ft}$. A strict biosecurity programme was maintained.

\section{Data collection and record keeping}

At the end of the trial, one male and one female broiler having near to pen average weight were taken from each pen. After fasting for 12 hours the birds were slaughtered and bled. Meat was collected from the breast, thigh and drumstick. Composition of meat was determined by the methods of AOAC (2005). Head, neck, shank, viscera, giblet (heart, liver and gizzard) and abdominal fat were removed for determination of meat yield parameters. Total viable microbial counts (TVC) were done for the microbial assessment of caecal digesta. TVC was calculated according to ISO (1995). 


\section{Data analysis}

The statistical analysis of body weight, body weight gain, feed consumption, feed conversion ratio (FCR), composition of meat, caecal microbial count, meat yield, internal organ and bone development were subjected to analysis of variance (ANOVA) in a completely randomized design (CRD) employing SAS (2009) statistical package program.

Table 1: Composition of experimental diets

\begin{tabular}{lccc}
\hline \multicolumn{1}{c}{ Ingredients } & Starter (0-21 days) & Grower (22-35 days) \\
\hline Corn & 51.4 & 61.7 \\
Soybean meal & 42.0 & 31.6 \\
Soybean oil & 3.4 & 3.2 \\
Dicalcium phosphate & 1.6 & 1.7 \\
Calcium carbonate & 0.8 & 0.9 \\
Salt & 0.3 & 0.3 \\
DL-Methionine & 0.2 & 0.2 \\
L-Lysine & 0.1 & 0.1 \\
Vitamin-Mineral Premix & 0.3 & 0.3 \\
\hline Calculated chemical composition (\%) & & \\
\hline Dry matter \% & 86.8 & 87.1 \\
Metabolizable energy (Kcal/kg) & 2985 & 3070 \\
Crude Protein\% & 22.5 & 20.1 \\
Lysine \% & 1.4 & 1.1 \\
Cystine \% & 0.4 & 0.3 \\
Methionine \% & 0.6 & 0.6 \\
Methionine + Cystine \% & 1.0 & 0.9 \\
Threonine \% & 2.0 & 0.8 \\
Histine \% & 0.6 & 0.5 \\
Arginine \% & 1.7 & 1.3 \\
Isoleucine \% & 1.1 & 0.8 \\
Leucine \% & 2.0 & 1.6 \\
Phenylalanine \% & 1.2 & 0.9 \\
Valine\% & 1.2 & 0.9 \\
Calcium \% & 0.9 & 0.9 \\
Available phosphorus \% & 0.5 & 0.5 \\
\hline
\end{tabular}

\section{Results and Discussion}

\section{Growth performance}

Growth performances are presented in Table 2. At 4th week of age, the body weight of the probiotic group was significantly $(\mathrm{P}<0.05)$ higher than the control group. At the 
end of study, body weight and total body weight gain in broilers fed with antibiotic, probiotic and green tea were significantly higher than in the control group $(\mathrm{P}<0.05)$. Feed intake of broilers at 4th week of age in the control group was significantly higher than in the green tea group, and higher than in the antibiotic group at 5th week of age. Total feed intake was higher in the control group than the supplemented groups $(\mathrm{P}<0.05)$. The FCR was significantly $(\mathrm{P}<0.05)$ improved at 5 th week of age in the antibiotic group than the control group. However, total FCR was improved $(P<0.05)$ in the supplemented groups than the control group.

Table 2: Growth performance of broilers in different treatment groups

\begin{tabular}{|c|c|c|c|c|c|}
\hline \multirow[t]{2}{*}{ Parameter } & \multicolumn{4}{|c|}{ Treatments } & \multirow[t]{2}{*}{ PSE } \\
\hline & Control & Antibiotic & Probiotics & Green tea & \\
\hline \multicolumn{6}{|c|}{ Body weight (g/bird) } \\
\hline Day old & 44.8 & 44.5 & 44.3 & 44.0 & 0.7 \\
\hline $1^{\text {st }}$ week & 159.0 & 154.3 & 150.3 & 152.0 & 6.0 \\
\hline $2^{\text {nd }}$ week & 385.0 & 384.3 & 391.0 & 388.25 & 15.9 \\
\hline $3^{\text {rd }}$ week & 662.3 & 649.3 & 672.0 & 657.3 & 39.2 \\
\hline $4^{\text {th }}$ week & $959.3^{b}$ & $981.8^{\mathrm{ab}}$ & $1008.5^{\mathrm{a}}$ & $984.8^{\mathrm{ab}}$ & 19.1 \\
\hline $5^{\text {th }}$ week & $1412.5^{b}$ & $1495.0^{\mathrm{a}}$ & $1485.0^{\mathrm{a}}$ & $1465.0^{\mathrm{a}}$ & 26.1 \\
\hline \multicolumn{6}{|c|}{ Body weight gain (g/bird) } \\
\hline $1^{\text {st }}$ week & 114.3 & 109.8 & 106.0 & 108.0 & 6.0 \\
\hline $2^{\text {nd }}$ week & 226.0 & 230.0 & 240.8 & 236.3 & 13.3 \\
\hline $3^{\text {rd }}$ week & 277.3 & 265.0 & 281.0 & 269.0 & 46.8 \\
\hline $4^{\text {th }}$ week & 297.0 & 332.5 & 336.0 & 327.5 & 38.6 \\
\hline $5^{\text {th }}$ week & $453.3^{b}$ & $513.3^{\mathrm{a}}$ & $476.5^{\mathrm{ab}}$ & $480.3^{\mathrm{ab}}$ & 26.2 \\
\hline Total & $1367.8^{b}$ & $1450.5^{\mathrm{a}}$ & $1440.8^{a}$ & $1421.0^{\mathrm{a}}$ & 25.9 \\
\hline \multicolumn{6}{|c|}{ Feed intake (g/bird) } \\
\hline $1^{\text {st }}$ week & 145.1 & 145.8 & 142.7 & 139.3 & 4.1 \\
\hline $2^{\text {nd }}$ week & 349.4 & 354.1 & 347.8 & 341.5 & 11.8 \\
\hline $3^{\text {rd }}$ week & 522.6 & 536.2 & 537.0 & 530.3 & 13.5 \\
\hline $4^{\text {th }}$ week & $723.5^{a}$ & $694.9 \mathrm{ab}$ & $708.3^{\mathrm{ab}}$ & $681.6^{\mathrm{b}}$ & 18.9 \\
\hline $5^{\text {th }}$ week & $974.6^{\mathrm{a}}$ & $929.0^{\mathrm{b}}$ & $944.0^{\mathrm{ab}}$ & $942.3^{\mathrm{ab}}$ & 26.2 \\
\hline Total & $2715.1^{\mathrm{a}}$ & $2659.9 \mathrm{bc}$ & $2679.8^{b}$ & $2635.1^{c}$ & 22.0 \\
\hline \multicolumn{6}{|c|}{ FCR (feed/gain) } \\
\hline $1^{\text {st }}$ week & 1.3 & 1.3 & 1.3 & 1.3 & 0.1 \\
\hline $2^{\text {nd }}$ week & 1.5 & 1.5 & 1.4 & 1.5 & 0.1 \\
\hline $3^{\text {rd }}$ week & 1.9 & 2.1 & 2.0 & 2.0 & 0.4 \\
\hline $4^{\text {th }}$ week & 2.4 & 2.2 & 2.1 & 2.1 & 0.2 \\
\hline $5^{\text {th }}$ week & $2.2^{\mathrm{a}}$ & $1.8^{\mathrm{b}}$ & $2.0^{\mathrm{ab}}$ & $2.0^{\mathrm{ab}}$ & 0.1 \\
\hline Total & $2.0^{\mathrm{a}}$ & $1.8^{\mathrm{b}}$ & $1.6^{b}$ & $1.6^{b}$ & 0.0 \\
\hline
\end{tabular}

$\mathrm{a}, \mathrm{b}, \mathrm{c}$ Values with different superscripts in the same row differ significantly $(\mathrm{P}<0.05)$. PSE $=$ Pooled Standard Error. 
Addition of probiotic and green tea in the poultry feed increased weight gain and improved FCR. This is in general agreement with Anjum et al. (2005) who obtained similar results with multi-strain probiotics. Ahmad and Taghi (2006) found that broiler supplemented with probiotic (B. subtilis and B. licheniformis) had significantly higher body weight gain during the grower phase (21-42 days) than control. The role of probiotics as effective alternatives to antibiotic growth promoter in animal nutrition has been reported by many researchers (Ghadban, 2002; Patterson and Burkholder, 2003). Beneficial effects of probiotics on broiler performance (Shim et al., 2012; Ashayerizadeh et al., 2009) have been reported. Biswas and Wakita (2001) reported a higher body weight gain when $0.5 \%$ green tea powder was added to the feed for broilers. On the other hand, Yang et al. (2003) observed no differences with antibiotic and $0.5 \%$ green tea by-products, but body weight was decreased when green tea byproducts were fed at 1\%. Sarker et al. (2010) observed no changes in body weight and body weight gain of broilers fed green tea and fermented green tea at $0.5 \%$ and $1 \%$. Mountzouris et al. (2007) suggested that probiotics and plant extracts aid digestion and immunity.

The feed intake of probiotic and green tea groups was significantly lower than control group, in agreement with the results of Shim et al. (2012) and Afsharmanesh and Sadaghi (2014). The result is consistent with that of Eseceli and Demir (2010) and Erdogan (2007). They reported that probiotic decreased feed intake. Biswas and Wakita (2001) reported a lower feed intake when $1 \%$ green tea powder was added to broiler feed for. However, Shomali et al. (2012) found no significant differences in feed intake.

The effect of probiotic on FCR is in close agreement with Rahimi (2009) and Zhou et al. (2010). They found that supplementing with B. subtilis and B. licheniformis improved feed conversion efficiency. Moreover, Anjum et al. (2005) showed that FCR was significantly improved in chicks fed on protexin, a multi-strain probiotic. Panda et al. (2008) reported that dietary B. subtilis and B. licheniformis enhanced feed efficiency in White Leghorn Breeders. Biswas and Wakita (2001) reported improved FCR with green tea at $1 \%$ on broiler. Uuganbayar et al. (2006) found better FCR with green tea at $1 \%$ in laying hens. However, Shomali et al. (2012) found no significant difference in FCR in broilers. The improved performance and FCR upon the supplementation with probiotics and green tea may be due to the increased activity of digestive enzymes caused by probiotic and green tea polyphones particularly catechins, the most abundant of which is epigallocatechin gallate.

\section{Dressing parameters, bone development and meat yield of broiler}

Dressing parameters were not affected by the supplementation of green tea and probiotic except gizzard, caeca and wing weight (Table 3). Broilers fed green tea showed heavier $(\mathrm{P}<0.05)$ caeca and wings than antibiotic group, whereas heavier gizzard was observed in antibiotic group than probiotic group. Thigh bone, thigh length, drumstick bone and drumstick length did not differ significantly $(\mathrm{P}>0.05)$ among groups (Table 4). Meat yield of broiler was not significantly $(\mathrm{P}>0.05)$ different 
between groups (Fig. 1). Abdominal fat content was lower in broilers fed green tea and probiotic compared with those fed antibiotic. In agreement, Luiz et al. (2012) reported that broilers fed probiotic had less abdominal fat than the antibiotic and control groups. Similarly, Xiaolu et al. (2012) reported that supplementation with $B$. licheniformis decreased fat content.

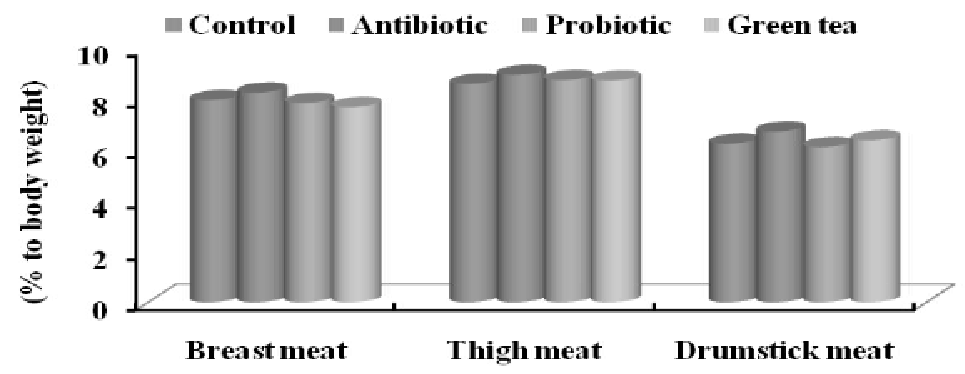

Fig. 1: Meat yield of broiler in different treatment groups.

Table 3: Dressing parameters of broiler in different treatment groups

\begin{tabular}{l|cccccc}
\hline \multirow{2}{*}{$\begin{array}{c}\text { Parameter (\% related to } \\
\text { body weight) }\end{array}$} & \multicolumn{4}{c|}{ Treatment } & \multirow{2}{*}{ PSE } \\
\cline { 2 - 5 } & Control & Antibiotic & Probiotic & Green tea & \\
\hline Blood & 4.9 & 4.5 & 5.2 & 5.0 & 0.7 \\
Feather & 3.4 & 3.7 & 3.8 & 3.6 & 0.4 \\
Skin & 6.6 & 6.6 & 5.9 & 5.9 & 1.0 \\
Head & 2.3 & 2.4 & 2.5 & 2.6 & 0.2 \\
Neck & 2.1 & 2.1 & 2.1 & 2.1 & 0.4 \\
Liver & 2.5 & 2.4 & 2.6 & 2.2 & 0.4 \\
Kidney & 0.5 & 0.5 & 0.4 & 0.4 & 0.1 \\
Heart & 0.4 & 0.4 & 0.4 & 0.4 & 0.0 \\
Abdominal fat & 0.9 & 1.1 & 0.9 & 0.7 & 0.4 \\
Gizzard & $1.8^{\mathrm{ab}}$ & $1.9^{\mathrm{a}}$ & $1.6^{\mathrm{b}}$ & $1.9^{\mathrm{ab}}$ & 0.2 \\
Ceca & $0.7^{\mathrm{ab}}$ & $0.5^{\mathrm{b}}$ & $0.6^{\mathrm{b}}$ & $1.0^{\mathrm{a}}$ & 0.2 \\
Wing & $5.3^{\mathrm{ab}}$ & $5.1^{\mathrm{b}}$ & $5.3^{\mathrm{ab}}$ & $5.9^{\mathrm{a}}$ & 0.4 \\
\hline
\end{tabular}

a,bValues with different superscripts in the same row differ significantly $(\mathrm{P}<0.05)$. PSE $=$ Pooled Standard Error.

Novak et al. (2011) found that supplementation with B. subtilis and B. licheniformis increased weight of wings. However, yield of wing in probiotic group was not significant in this study but numerically higher than the antibiotic group. Habibi et al. (2013) observed most abdominal fat and relative liver weight in the protexin probiotic group and wing weight in bactocell probiotic group, which disagree with our results. Supplementation of green tea at $0.25 \%$ in the present study showed lower caeca weight. Sarker et al. (2010) observed lower caeca weight in broilers fed green tea at $0.5 \%$, but the weight increased when green tea was fed at $1 \%$. Supplementation of 
probiotic and green tea in the present study had no effect on meat yield. Conversely, Molnar et al. (2013) reported that Bacillus spp. supplementation led to significantly higher breast yield and lower thigh meat yield. Biswas and Wakita (2001) reported higher thigh meat and lower wing meat when green tea was fed at $1.5 \%$. Other authors (Moreira et al., 2001; Loddi et al., 2002) found no significant difference in carcass yield between birds fed probiotic and control diet.

Table 4: Bone development of broiler in different treatment groups

\begin{tabular}{|c|c|c|c|c|c|}
\hline \multirow{2}{*}{$\begin{array}{c}\text { Parameter ( } \% \text { related to } \\
\text { body weight })\end{array}$} & \multicolumn{4}{|c|}{ Treatment } & \multirow[t]{2}{*}{ PSE } \\
\hline & Control & Antibiotic & Probiotic & Green tea & \\
\hline Thigh bone & 1.1 & 1.3 & 1.4 & 1.4 & 0.2 \\
\hline Drumstick bone & 1.9 & 1.8 & 1.9 & 2.0 & 0.2 \\
\hline Thigh length & 0.4 & 0.4 & 0.4 & 0.4 & 0.0 \\
\hline Drum length & 0.6 & 0.6 & 0.6 & 0.6 & 0.0 \\
\hline
\end{tabular}

$a, b$ Values with different superscripts in the same row differ significantly $(\mathrm{P}<0.05)$. PSE $=$ Pooled Standard Error.

\section{Composition of broiler meat}

Incorporation of antibiotic and green tea increased $(\mathrm{P}<0.5)$ crude protein content while probiotic and green tea decreased $(\mathrm{P}<0.5)$ fat content in broiler meat compared to the control group (Table 5). Moisture and ash content did not differ between groups. Upon the supplementation with green tea, crude protein content increased, and ether extract content decreased in the meat in both antibiotic and probiotic groups. Similarly, Sarker et al. (2010) found that crude protein content of meat increased significantly in broilers fed $1.0 \%$ fermented green tea compared to other treatments, but ether extract was not changed. The present result is consistent with the findings of Xiaolu et al. (2012), who reported that the supplementation with $B$. licheniformis resulted in increased protein content. In contrast, Yang et al. (2003) observed lower crude protein in broilers fed green tea at $0.5 \%$ than in those fed antibiotics, but no changes in ether extract content.

Table 5: Composition of broiler meat in different treatment groups

\begin{tabular}{l|c|c|c|c|c}
\hline \multirow{2}{*}{ Parameter (\%) } & \multicolumn{4}{|c|}{ Treatments } & \multirow{2}{*}{ PSE } \\
\cline { 2 - 5 } & Control & Antibiotic & Probiotic & Green tea & \\
\hline Moisture & 74.8 & 74.6 & 74.9 & 74.7 & 0.3 \\
Crude protein & $22.0^{\mathrm{b}}$ & $22.4^{\mathrm{a}}$ & $22.2^{\mathrm{ab}}$ & $22.4^{\mathrm{a}}$ & 0.2 \\
Ether extract & $2.4^{\mathrm{a}}$ & $2.1^{\mathrm{ab}}$ & $2.0^{\mathrm{b}}$ & $2.0^{\mathrm{b}}$ & 0.2 \\
Ash & 0.8 & 0.9 & 2.0 & 0.9 & 0.2 \\
\hline
\end{tabular}

$\mathrm{a}, \mathrm{b}$ Values with different superscripts in the same row differ significantly $(\mathrm{P}<0.05)$. PSE $=$ Pooled Standard Error. 


\section{Total caecal microbial count}

Supplementation of antibiotic, probiotic and green tea significantly decreased $(\mathrm{P}<0.05)$ total microbial number in the caeca compared to the control group (Fig. 2). The present finding supports the views of Molnar et al. (2012) and Adebiyi et al. (2012). It was previously reported that green tea extracts improved microflora balance and inhibited pathogenic bacteria (Hara-Kudo et al., 2005). These effects are often concerned with polyphenols, which are mainly composed of catechins. Tea catechins are bactericidal and inhibit the growth of bacterial spores (Hara-Kudo et al., 2005). It was previously reported that green tea extract enhances the growth of some Bifidobacteria, selectively inhibits the growth of clostridia and has no effect on other intestinal bacteria in-vitro. The maintenance of the gut environment is now known to be a key part of reducing disease in poultry. Yakhkeshi et al. (2011) opined that plant extract and probiotics reduced pathogenic bacteria in digestive tract of broilers, which can improve intestinal health.

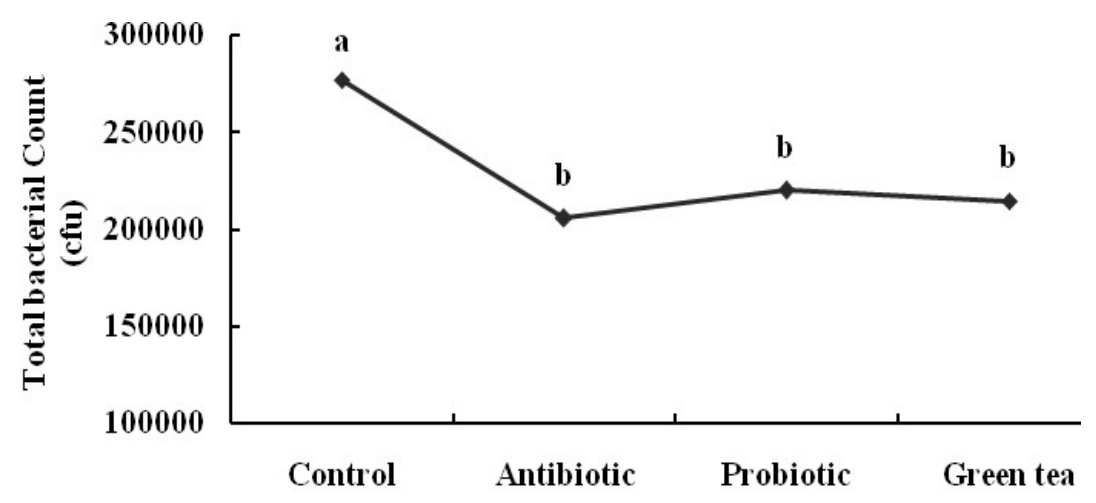

Fig. 2: Caecal microbial number in different treatment groups (cfu/g).

\section{Conclusions}

Probiotic and green tea improve growth parameters, internal organs, composition of meat and reduction of microbial population, in a similar way to antibiotic. Use of green tea and probiotic as feed additives in poultry diet, can make antibiotic-free poultry meat, which will be safer for public health.

\section{Acknowledgements}

Authors acknowledge Bangladesh Agricultural University Research System (BAURES) for funding.

\section{References}

Adebiyi OA, Makanjuola BA, Bankole TO, Adeyori AS 2012: Yeast culture (Saccharomyces cerevisae) supplementation: Effect on the performance and gut morphology of broiler birds. Global Journal of Science Frontier Research Biological Science 12 25-29. 
Afsharmanesh M, Sadaghi B 2014: Effects of dietary alternatives (probiotic, green tea powder, and Kombucha tea) as antimicrobial growth promoters on growth, ileal nutrient digestibility, blood parameters, and immune response of broiler chickens. Comparative Clinical Pathology 23 717-724.

Ahmad K, Taghi G 2006: Effect of probiotic on performance and immunocompetence in broiler chicks. Journal of Poultry Science 43 296-300.

Alexopoulos IL, Georgoulakis A, Tzivara SK, Kritas A, Siochu SC, Kyriakis 2004: Field evaluation of the efficacy of a probiotic containing Bacillus licheniformis and Bacillus subtilis spores, on the health status and performance of sows and their litters. Journal of Animal Physiology and Nutrition 88 281-292.

Anjum M I, Khan AG, Azim A, Afzal M 2005: Effect of dietary supplementation of multi strain probiotic on broiler growth performance. Pakistan Veterinary Journal 25(1) 25-29.

AOAC 2005: Official Methods of Analysis (18th edition) Association of Official Analytical, Chemists International, Maryland, USA.

Ashayerizadeh A, Dabiri N, Ashayrizadeh O, Mizadeh KH, Roshanfekr H, Mamooee M 2009: Effects of dietary antibiotic, probiotic and prebiotic as growth promoter on growth performance, carcass characteristics and hematological indices of broiler chickens. Pakistan Journal of Biological Sciences 12(1) 52-57.

Biswas MAH, Wakita M 2001: Effect of dietary Japanese green tea powder supplementation on feed utilization and carcass profiles in broilers. Journal of Poultry Science 38 50-57.

Cobb Breeder Management Guide 2012: Available via https://www.cobb-vantress.com

Coppola MM, Turns CG 2004: Probioticos e resposta immune. Ciencia Rural 34(4) 12971303.

Erdogan Z 2007: The use of antibiotic and probiotic in broiler diets. Lalaham- HayvancilikArastirmaenstitusu-Dergisi 39 37-69.

Eseceli H, Demir E, Degirmencioglu N, Bilgic M 2010: The effects of "Bio-Mos" mannan oligosaccharide and antibiotic. Journal of Animal and Veterinary Advances 9(2) 392-395.

FAO/WHO 2002: Working group report on drafting guidelines for the evaluation of probiotics in food. 30 April-1 May, London, UK and Ontario, Canada. FAO, Rome, Italy.

Fuller R 1989: Probiotics in man and animals. Journal of Applied Biotechnology 66 365-378.

Ghadban GS 2002: Probiotics in broiler production-A review. Arch. Geflugelkd 66 49-58.

Habibi S, Khojasteh S, Jafar M 2013: The effect of bactocell and protexin probiotics on performance and carcass characteristics of broiler. Journal of Novel Applied Sciences 2(11) 565-570.

Hara-Kudo Y, Yamasaki A, Sasaki M, Okubo T, Minai Y, Haga M, Kondo K, SugitaKonishi Y 2005: Antibacterial action on pathogenic bacteria spore by green tea catechins. Journal of science food and Agriculture 85 2354-2361. 
Hossain ME, Ko SY, Park KW, Firman JD, Yang CJ 2012a: Evaluation of green tea byproduct and green tea plus probiotics on the growth performance, meat quality and immunity of growing-finishing pig. Animal Production Science 52 857-866.

Hossain ME, Ko SY, Yang CJ 2012b: Dietary supplementation of green tea by-products on growth performance, meat quality, blood parameters and immunity in finishing pigs. Journal of Medicinal Plants Research 6(12) 2458-2467.

International Standard Organization (ISO) 1995: Recommendation of the meeting of the subcommittee, International Organization for Standardization, on meat and meat products. ISO/TC-36/Sc-6. PP. 10-18.

Ishihara N, Chu DC, Akachi S, Juneja 2001: Improvement of intestinal microflora balance and prevention of digestive and respiratory organ diseases in calves by green tea extracts. Livestock Production Science 68 217-222.

Ko SY, Bae IH, Yee ST, Lee SS, Uuganbayar D, Oh JI, Yang CJ 2008: Comparison of the effect of green tea by-product and green tea probiotics on the growth performance, meat quality, and immune response of finishing pigs. Asian-Australasian Journal of Animal Sciences 21(10) 1486-1494.

Kyriakis SC, Tsiloyiannis VK, Vlemmas J, Sarris K, Tsinas AC, Alexopoulos A, Jansegers L 1999: The effect of probiotics LSP 122 on the control of post-weaning diarrhoea syndrome of piglets. Research of Veterinary Science 67 223-228.

Loddi MM, Gonzales E, Takita TS, Mendes AAM, Roça RO 2000: Uso de probiótico e antibiótico sobre o desempenho, rendimento equalidade de carcaça de frangos de corte. Revista Brasileira de Zootecnia 29(4) 1124-1131.

Luiz G, Aristides A, Oba A, Shimokomaki M 2012: The effects of biotic additives on growth performance and meat qualities of broiler. International Journal of Poultry Science 11(9) 599-604.

Molnar AK, Podmaniczky B, KurtiP, Tenk I, Glavits R, Virag GY, Szabo ZS 2012: Effect of different concentrations of Bacillus subtilis on growth performance, carcasses quality, gut microflora and immune response of broiler chickens. British Journal of Poultry Science 52(6) 658-665.

Moreira J, Mendes AA, Garcia EA, Garcia RG, Almeida ICL, JR, JGC 2001: Efeito do uso do probiótico sobre o desempenho e rendimento de carcaça em frangos de corte. In: XXXVIII Reunião Anual da SBZ, Piracicaba. Anais Piracicaba p-852-854.

Mountzouris KC, Tsirtsikos P, Kalamara E, Nitsch S, Schatzmayr G, Fegeros K 2007: Evaluation of the efficacy of a probiotic containing Lactobacillus, Bacillus, Bifidobacterium, Enterococcus, and Pediococcus strains in promoting broiler performance and modulating cecal microflora composition and metabolic activities. Journal of Poultry Science 86 309-317.

Mukhatar H, Ahmad N 1999: Mechanism of cancer chemopreventive activity of green tea. Proceedings of the Society for Experimental Biology and Medicine 220 234-238. 
Murshed MA, Abudabos AM: 2015. Effects of dietary inclusion of probiotic, prebiotic and symbiotic on growth performance of broiler chickens. Brazilian Journal of Poultry Science 117 99-104.

Nishida T, Eruden B, Hosoda K, Nakagawa K, Miyazawa T, Shioya S 2006: Effects of green tea (Camellia sinensis) waste silage and polyethylene on ruminal fermentation and blood components in cattle. Asian-Australasian Journal of Animal Sciences 19 1728-1736.

Novak R, Cervek M, Gorjanc G, Levart A 2011: Effect of two probiotic additives containing Bacillus spores on carcass characteristics, blood lipid and cecal volatile fatty acids in meat type chicken. Journal of Animal Physiology and Animal Nutrition 95 424-433.

Panda AK, Rao SSR, Raju S, Sharma S 2008: Effect of probiotics feeding on egg production and quality, yolk cholesterol and humeral immune response of White Leghorn layer breeders. Journal of the Science of Food and Agriculture 88 43-47.

Patterson JA, Burkholder KM 2003: Application of prebiotics and probiotics in poultry production. Journal of Poultry Science 82 627-631.

Rahimi M: 2009: Effects of probiotics supplementation on performance and humoral immune response of broiler chickens. Book of Proceedings, $2^{\text {nd }}$ Mediterranean Summit of WPSA, 67-69.

Sarker MSK, Ko SY, Kim GM, Yang CJ 2010: Effects of Camellia sinensis and mixed probiotics on the growth performance and body composition in broiler. Journal of Medicinal Plants Research 4 546-550.

SAS 2009: SAS User's Guide, Version 9.1 edn. SAS Institute, Cary, NC.

Shim YH, Ingali SL, Kim JS, Seo DK, Lee SC, Kwon IK 2012: A multi-microbe probiotic formulation processed at low and high drying temperatures: effects on growth performance, nutrient retention and caecal microbiology of broilers. Journal of British Poultry Science 53 482-490.

Shomali T, Mosleh T, Nazifi S, 2012: Two weeks of dietary supplementation with green tea powder does not affect performance, D-xylose absorption, and selected serum parameters in broiler chickens. Comparative Clinical Pathology 21 1023-1027.

Tannock GW 1999: What we know and need to know. Journal of Advance Biotechnology 17 691-693.

Thinh N H, Vinh N T, Linh N V, Phuong Giang N T, Doan B H and Dang P K 2018: Effect of dietary supplementation with green tea powder on performance characteristic, meat organoleptic quality and cholesterol content of broilers. Livestock Research for Rural Development 30160.

Uuganbayar D, Shin IS, Yang CJ 2006: Comparative performance of hens fed diets containing Korean, Japanese and Chinese green tea. Asian-Australasian Journal of Animal Science 19 1190-1196.

Xiaolu L, Yan H, Lv X, Qianqian K, Zhang H, Jiye K 2012: Growth performance and meat quality of broiler chickens supplemented with Bacillus licheniformis in drinking water. Asian-Australasian Journal of Animal Science 25 682-689. 
Yakhkeshi S, Rahimi S, Gharib Naseri K 2011: The Effects of comparison of herbal extracts, antibiotic, probiotic and organic acid on serum lipids, immune response, GIT microbial population, intestinal morphology and performance of broilers. Journal of Medicinal Plants 10 80-95.

Yang CJ, Yang IY, Oh DH, Bae IH, Cho SG, Kong IG, Uuganbayar D, Nou IS, Choi KS 2003: Effect of green tea by-product on performance and body composition in broiler chicks. Asian-Australasian Journal of Animal Sciences 16 867-872.

Zhou X, Wang Y, Wu RJ, Zhang B 2010: Effect of dietary probiotic on growth performance, chemical composition and meat quality of Guangxi Yellow Chicken. Journal of Poultry Science 89 588-593. 